\title{
Pea seed-borne mosaic virus Pathosystem Drivers under Mediterranean-Type Climatic Conditions: Deductions from 23 Epidemic Scenarios
}

B. S. Congdon, School of Agriculture and Environment and Institute of Agriculture, Faculty of Science, University of Western Australia, Crawley, WA 6009, Australia; B. A. Coutts, Crop Protection Branch, Department of Agriculture and Food Western Australia, Perth, WA 6983, Australia; M. Renton, School of Agriculture and Environment and Institute of Agriculture, Faculty of Science, University of Western Australia; and R. A. C. Jones, Institute of Agriculture, Faculty of Science, University of Western Australia, and Crop Protection Branch, Department of Agriculture and Food Western Australia

\begin{abstract}
Drivers of Pea seed-borne mosaic virus (PSbMV) epidemics in rainfed field pea crops were examined under autumn to spring growing conditions in a Mediterranean-type environment. To collect aphid occurrence and PSbMV epidemic data under a diverse range of conditions, 23 field pea data collection blocks were set up over a 6-year period (2010 to 2015) at five locations in the southwest Australian grain-growing region. PSbMV infection levels in seed sown (0.1 to $13 \%)$, time of sowing (22 May to 22 June), and cultivar (Kaspa or PBA Twilight) varied with location and year. Throughout each growing season, rainfall data were collected, leaf and seed samples were tested to monitor PSbMV incidence in the crop and transmission from harvested seed, and sticky traps were used to monitor flying aphid numbers. Winged migrant Acyrthosiphon kondoi, Lipaphis erysimi, Myzus persicae, and Rhopalosiphum padi were identified in green tile traps in 2014 and 2015. However, no aphid

colonization of field pea plants ever occurred in the blocks. The deductions made from collection block data illustrated how the magnitude of PSbMV spread prior to flowering is determined by two primary epidemic drivers: (i) PSbMV infection incidence in the seed sown, which defines the magnitude of virus inoculum source for within-crop spread by aphids, and (ii) presowing rainfall that promotes background vegetation growth which, in turn, drives early-season aphid populations and the time of first arrival of their winged migrants to field pea crops. Likely secondary epidemic drivers included wind-mediated PSbMV plant-to-plant contact transmission and time of sowing. PSbMV incidence at flowering time strongly influenced transmission rate from harvested seed to seedlings. The data collected are well suited for development and validation of a forecasting model that informs a Decision Support System for PSbMV control in field pea crops.
\end{abstract}

Pea seed-borne mosaic virus (PSbMV; family Potyviridae, genus Potyvirus) infects field pea (Pisum sativum) crops worldwide, causing substantial yield and seed quality losses, especially when the seed sown has infection levels of $>0.5 \%$ and incidences reach high levels early in the life of the crop (Ali and Randles 1998; Coutts et al. 2008, 2009; Kraft and Hampton 1980; Latham and Jones 2001b). However, late infection typically induces minimal or no yield losses (Ali and Randles 1998; Chiko and Zimmer 1978; Kraft and Hampton 1980). Despite its detrimental effects on seed yield and quality, PSbMV foliage symptoms are often subtle in pea crops, causing the impact of the virus to be underestimated or go unnoticed (Khetarpal and Maury 1987). Sowing PSbMV-infected seed stocks produces seed-infected plants scattered at random throughout a pea crop. These act as the primary inoculum source for plant-to-plant transmission by both aphid vectors in a nonpersistent manner (Khetarpal and Maury 1987) and wind-mediated contact transmission (Congdon et al. 2016b). Several aphid species are known to transmit PSbMV, including Aphis craccivora (cowpea aphid), Acyrthosiphon pisum (pea aphid), Brevicoryne brassicae (cabbage aphid), Myzus persicae (green-peach aphid), and Rhopalosiphum padi (oat aphid) (Aapola and Mink 1973; Coutts et al. 2009; Gonzalez and Hagedorn 1971; Inouye 1967; Khetarpal and Maury 1987). PSbMV spread by windmediated contact transmission is also likely to be important due to its role in enlarging initial PSbMV infection foci, each centered on a seed-infected plant prior to aphid arrival in pea crops (Congdon et al. 2016b).

Corresponding author: B. Congdon;

E-mail: benjamin.congdon@ research.uwa.edu.au

*The $\boldsymbol{e}$-Xtra logo stands for "electronic extra" and indicates that two supplementary figures are published online.

Accepted for publication 27 January 2017.

(c) 2017 The American Phytopathological Society
In the Mediterranean-type climate of the southwest Australian graingrowing region (grainbelt), field pea is an important crop legume. It is sown mainly in finely textured neutral to alkaline soils to which narrow-leafed lupin (Lupinus angustifolius), the predominant crop legume grown, is poorly adapted (Gladstones 1998; Siddique et al. 1999). In the rainfed autumn to spring (May to October) annual growing season, legumes are grown in rotation with wheat (Triticum aestivum) and canola (Brassica napus) crops, providing them with several benefits such as nitrogen fixation and weed and fungal disease breaks (Chalk 1998; Siddique et al. 1999). Currently, PSbMV infection is widespread in commercial seed stocks of semileafless field pea cultivars widely sown in this region (Congdon et al. 2016a; Coutts et al. 2008). Although rarely sown in the grainbelt in recent years, PSbMV also infects the grain legume crops chickpea (Cicer arietinum), faba bean (Vicia faba), lentil (Lens culinaris), and various vetches (Vicia spp.). However, narrow-leafed lupin is a non-host (Latham and Jones 2001a,b). PSbMV is a specialist virus with a narrow host range in the Fabaceae family and no alternative weed hosts have been found in the grainbelt (Vincent et al. 2014); however, its seedborne nature allows it to persist in harvested seed stocks over the hot and dry summer period between annual growing seasons.

Research on other nonpersistently aphidborne viruses infecting narrow-leafed lupin crops found that time of aphid arrival in the crop was an important primary driver of virus spread in the grainbelt (Maling et al. 2008; Thackray et al. 2004). High amounts of rainfall during early to mid-autumn (March and April) prior to sowing allow background vegetation (weeds, pasture plants, and crop volunteers) to build up, enabling aphid populations to do the same before migrating to crops. When this occurs, winged aphids arrive early in the life of the crop, causing virus spread in young plants and widespread crop infection by the end of the growing season (Jones 2001; Jones et al. 2010; Maling et al. 2008, 2010; Thackray et al. 1998, 2004, 2009). The PSbMV-field pea pathosystem differs from these others in which aphids colonize the crops because aphid colonization of field pea has never been recorded in the grainbelt (Coutts et al. 2009). Control strategies effective for nonpersistently aphidborne grain legume viruses and also advised for PSbMV management in the region 
include (i) using stubble retention, narrow row spacing, and higher sowing rates to decrease aphid landing rates or increase canopy cover to "shade out" seed-infected plants; (ii) sowing later in some locations to avoid coinciding with early autumn aphid populations; and (iii) sowing at a greater depth to decrease survival of virus-infected seedlings (Coutts 2016; Jones 2001; Jones and Proudlove 1991). High PSbMV incidences found in commercial crops of frequently grown field pea cultivars in the grainbelt combined with knowledge of their likely effect on seed yield and quality demonstrates a need for more effective management of the virus (Congdon et al. 2016a; Coutts et al. 2008, 2009; Latham and Jones 2001a).

To provide the information needed to calibrate and validate forecasting models for several other aphidborne viruses of annual crops grown in the region, data collection blocks consisting of large square plots were sown at different locations over sufficient years to ensure that they represented a wide range of climatic scenarios. Forecasts from these models were used to inform Decision Support Systems (DSS) which assist growers and advisors in making virus and aphid management decisions prior to sowing (Maling et al. 2008, 2010; Thackray et al. 2004, 2009). The PSbMV-field pea pathosystem is likely to share many characteristics with these other grainbelt pathosystems but might also differ in some important aspects. To understand these similarities and differences, and generate data for a PSbMV forecasting model, sowing large square plots (data collection blocks) with field pea seed with a range of known infection levels at different sites over several growing seasons is required. Some of this kind of data are already available from field experiments designed for other purposes (Coutts et al. 2009). The aim of this study was to provide additional data from a wider range of sites, growing seasons, and PSbMV infection levels in seed sown. This article describes the use of 23 field pea data collection blocks sown in five locations over a 6-year period in the grainbelt to collect data throughout the growing season, including rainfall, winged migrant aphid numbers, and PSbMV incidence, as well as PSbMV transmission rates from harvested seed to seedlings.

\section{Materials and Methods}

Glasshouse-grown culture plants, sap inoculations, and virus isolates. All plants were maintained at 18 to $22^{\circ} \mathrm{C}$ in insect-proof glasshouses. For use as PSbMV culture hosts, plants of 'Kaspa' and 'PBA Twilight' field pea (both semidwarf, semileafless types) and 'Fiord' faba bean were grown in a sand/potting mix blend (50:50) or potting mix alone, respectively. All plants were sprayed regularly with the insecticide imidacloprid ( $0.125 \mathrm{~g} /$ liter) to ensure that aphids were absent. A culture of southwest Australian PSbMV isolate W1 originally obtained from

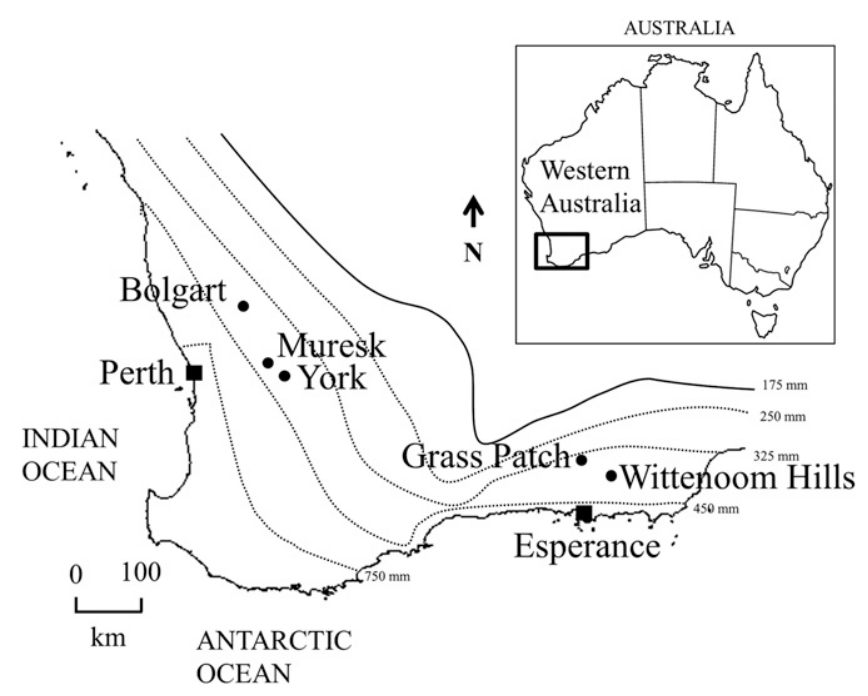

Fig. 1. Map of Australia showing where the southwest Australian grain-growing region (grainbelt) is located. Insert shows the 175- and 750-mm rainfall isohyets that make the outer and inner grainbelt boundaries, respectively, and the locations of the field pea data collection blocks (-) sown from 2010 to 2015. infected pea in 1998 (Latham and Jones 2001b) was maintained by serial mechanical inoculation of infective sap to plants of pea and faba bean. For mechanical inoculations, leaves from systemically PSbMV-infected plants were ground in $0.1 \mathrm{M}$ phosphate buffer, $\mathrm{pH}$ 7.2, and the infective sap was mixed with diatomaceous earth before being rubbed onto leaves. In enzyme-linked immunosorbent assay (ELISA), leaf samples from pea or faba bean plants infected with isolate $\mathrm{W} 1$ were used as the positive control and leaves from healthy plants as the negative control.

ELISA. To test for virus infection, pea leaf samples from data collection blocks or glasshouse-grown seedlings were extracted singly or in groups of 2 to $10(1 \mathrm{~g}$ per $20 \mathrm{ml})$ in phosphate-buffered saline (10 mM potassium phosphate, $150 \mathrm{mM}$ sodium chloride, Tween 20 at $5 \mathrm{ml} /$ liter, and polyvinyl pyrrolidone at $20 \mathrm{~g} /$ liter; $\mathrm{pH}$ 7.4) using a mixer mill (Retsch). Sample extracts were tested for PSbMV by doubleantibody sandwich ELISA, as described by Clark and Adams (1977). The polyclonal antiserum to PSbMV used was from DSMZ. All samples were tested in duplicate wells in microtiter plates. Sap extracts from known PSbMV-infected and healthy field pea or faba bean leaf samples were always included in paired wells to provide positive and negative controls, respectively. The substrate was $p$-nitrophenyl phosphate at $1.0 \mathrm{mg} / \mathrm{ml}$ in diethanolamine (pH 9.8) at $100 \mathrm{ml} /$ liter. Absorbance values at $405 \mathrm{~nm}$ were measured in a microplate reader (Bio-Rad Laboratories). Positive absorbance values were always at least 10 times those of the healthy sap. Virus incidence was estimated from grouped sample test results using the formula of Gibbs and Gower (1960).

Field pea data collection blocks. From 2010 to 2015, square data collection blocks ( 60 by $60 \mathrm{~m}$ ) of field pea were set up annually at two to three of five sites in the southwest Australian grainbelt (Fig. 1). The blocks were located at Bolgart $\left(31^{\circ} 32^{\prime} \mathrm{S}, 116^{\circ} 54^{\prime} \mathrm{E}\right)$ in 2013 to 2014 ; Grass Patch $\left(33^{\circ} 26^{\prime} \mathrm{S}, 121^{\circ} 56^{\prime} \mathrm{E}\right)$ in 2010 to 2015 ; Muresk $\left(31^{\circ} 75^{\prime} \mathrm{S}\right.$, $\left.116^{\circ} 68^{\prime} \mathrm{E}\right)$ in 2010,2011 , and 2015; Wittenoom Hills $\left(33^{\circ} 41^{\prime} \mathrm{S}\right.$, $\left.122^{\circ} 15^{\prime} \mathrm{E}\right)$ in 2010 to 2012 ; and York $\left(31^{\circ} 82^{\prime} \mathrm{S}, 116^{\circ} 80^{\prime} \mathrm{E}\right)$ in 2012 . Details of year, locations, cultivars, sowing dates, and PSbMV infection levels in seed sown are given in Table 1 . The blocks were sown between 22 May and 22 June each year at a seeding rate of $100 \mathrm{~kg} / \mathrm{ha}$ with 22-cm row spacing. They consisted of Kaspa alone from 2010 to 2011. However, from 2012 to 2015, a block of PBA Twilight was also present at each location. This made 23 blocks overall. With the exception of PBA Twilight at Bolgart in 2014, which was sown in the presence of residual wheat stubble on the soil surface (approximately $75 \%$ groundcover), every block was sown into bare earth.

Rainfall data were obtained for each block from the nearest Bureau of Meteorology weather station. For sites located at Muresk, Bolgart, York, and Wittenoom Hills, local stations $(<10 \mathrm{~km}$ from each site) were used. For the Grass Patch site, a station at Circle Valley (approximately $25 \mathrm{~km}$ from this site) was used.

To monitor aphid movement at all sites, a double-sided rectangular ( 15 by $7 \mathrm{~cm}$ ) yellow sticky trap (Bugs for Bugs) was positioned vertically on a metal stake $1.5 \mathrm{~m}$ off the ground at two opposite corners of the central 20-by-20-m square within each block (Supplementary Fig. S1). With the exception of the blocks of Kaspa and PBA Twilight located at Bolgart in 2014 and Muresk in 2015, yellow sticky traps were not set facing the prevailing wind direction and were susceptible to movement by wind currents. These yellow sticky traps were changed weekly and the total aphid numbers caught on each were counted (aphids caught on sticky traps were mostly damaged; therefore, no species identification was done). The beginning of migrant winged aphid activity over the blocks (i.e., first aphid arrival) was determined by the date when aphids were first caught. To check for any aphid colonization of field pea, plants in the central 20-by-20-m square were observed generally for nymphs during every visit. In addition, six leaves (from a mixture of bottom, middle, and top nodes) of each of 20 plants chosen arbitrarily from each block were examined in detail in the field for nymphs at 4-week intervals. In 2014 at Bolgart (K12 and T6) and 2015 at Muresk (K14 and T7), green tile traps consisting of a container ( 16 by 12 by $10 \mathrm{~cm}$ ) half-filled with a $30 \%$ dilution of polyethylene glycol in water were positioned in the center of each block to catch aphids. To accommodate increasing canopy height resulting from crop growth, a retort stand that held each trap in place was raised every 
week, as described by Thackray et al. (2005). The aphid specimens caught were collected once a week and examined to obtain overall aphid counts and identify the species present. For the purposes of site comparison, aphid counts from each of the two traps were added together for each site.

To monitor virus spread, every 2 weeks from postemergence until the beginning of crop senescence (final incidence), 100 shoot-tip samples each from a different plant were collected systematically in a Z-shaped pattern from within the central 20-by-20-m square inside each 60-by-60-m block, and tested individually or in groups of 2 to 10 for PSbMV by ELISA. To check for PSbMV-induced symptoms, individual plants and the crop canopy were inspected every 2 weeks. At the end of the growing season, the central 20-by-20-m squares within each block were harvested. Then, 1,000 seeds taken from a representative seed sample representing each block were sown in trays in an insectproof glasshouse (maintained at 18 to $22^{\circ} \mathrm{C}$ ), and shoot-tip samples taken from seedlings at the two-node growth stage and tested in groups of 10 for PSbMV by ELISA.

Statistical analysis. Linear regression was performed to test for a relationship between total March and April rainfall and date of first aphid arrival at each site (when both cultivars were present at the same site, an average arrival date was used). A log-transformation of rainfall was used to ensure that assumptions of normality and homogeneity of variance were met. Multiple linear regression was performed to test whether (i) PSbMV incidence at flowering could be explained by day of first aphid arrival (day number in a 365-day year) and PSbMV infection level in seed sown and (ii) transmission rate from harvested seed could be explained by PSbMV incidence at flowering and cultivar sown (as a factor). For these, assumptions of normality and homogeneity of variance were checked using a Shapiro test and through regression of residuals against fitted values, respectively, in all analyses.

\section{Results}

Field pea data collection blocks. Virus symptoms. Plants infected with PSbMV via infected seed or early aphid or wind-mediated contact transmission were stunted (most severely in seed-infected plants) and their foliage showed signs of leaf chlorosis, mosaic, and curling. Plants that became infected at later growth stages rarely showed visible symptoms. Canopy depressions consisting of patches of stunted plants centered on seed-infected plants occurred within blocks. These were more noticeable when seed stocks with higher PSbMV infection levels were sown (Fig. 2).

Aphid arrival. For each site, when total March and April rainfall data were compared with total aphid numbers caught at different times on sticky traps, date of first aphid arrival was significantly influenced by rainfall $(P<0.001$; Fig. 3$)$. High amounts of rainfall during this period resulted in early first aphid arrival and low rainfall in late first aphid arrival. For example, when March and April rainfall was $<30 \mathrm{~mm}$, first aphid arrival was delayed until late August to midSeptember whereas, when March and April rainfall was $>50 \mathrm{~mm}$, first aphid arrival occurred from late July to early August. Data on numbers of aphids caught per trap per day at each block are discussed below in the "Block climatic, aphid, and PSbMV incidence data" section.

Aphid species. In 2014 at the Bolgart site (K12 and T6), which was surrounded by fields containing canola and wheat crops and mixedspecies (legume and grass) annual pasture, total winged migrant aphid numbers caught in both green tile traps commenced at 42 days after sowing (DAS). They then rose rapidly, peaking at 77 DAS before rapidly declining to low numbers after 90 DAS (Fig. 4A). After commencing at 42 DAS, $M$. persicae numbers caught remained minimal before

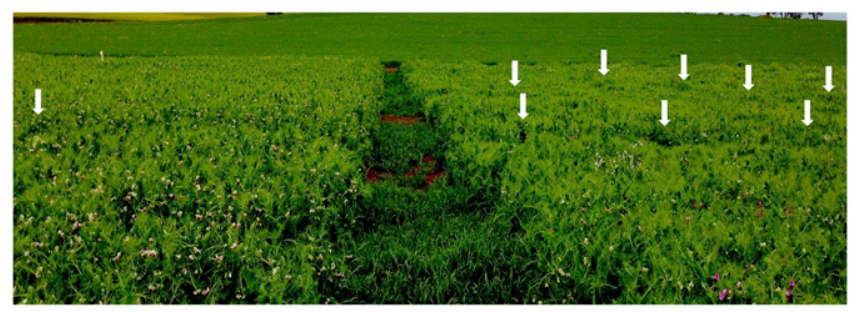

Fig. 2. Canopy depressions (white arrows) in blocks of field pea PBA Twilight (left) and Kaspa (right) at flowering time. These blocks were sown at Bolgart in 2013 with $2 \%$ (PBA Twilight) and 13\% (Kaspa) infected seed. They had 24\% (PBA Twilight) and 90\% (Kaspa) Pea seed-borne mosaic virus incidences at flowering. There were more obvious canopy depressions in the Kaspa block.

Table 1. Details of the field pea-Pea seed-borne mosaic virus (PSbMV) data collection blocks

\begin{tabular}{|c|c|c|c|c|c|}
\hline Block $^{\mathrm{a}}$ & Year & Location & Cultivar & Sowing date & PSbMV seed infection $(\%)^{b}$ \\
\hline K1 & 2010 & Wittenoom Hills & Kaspa & 31 May & 7 \\
\hline K2 & 2010 & Grass Patch & Kaspa & 2 June & 7 \\
\hline K3 & 2010 & Muresk & Kaspa & 1 June & 7 \\
\hline K4 & 2011 & Wittenoom Hills & Kaspa & 30 May & 2 \\
\hline K5 & 2011 & Grass Patch & Kaspa & 26 May & 2 \\
\hline K6 & 2011 & Muresk & Kaspa & 30 May & 2 \\
\hline K7 & 2012 & Wittenoom Hills & Kaspa & 10 June & 10 \\
\hline K8 & 2012 & Grass Patch & Kaspa & 10 June & 10 \\
\hline K9 & 2012 & York & Kaspa & 28 May & 10 \\
\hline $\mathrm{T} 1$ & 2012 & Wittenoom Hills & PBA Twilight & 10 June & 0.1 \\
\hline $\mathrm{T} 2$ & 2012 & Grass Patch & PBA Twilight & 10 June & 0.1 \\
\hline $\mathrm{T} 3$ & 2012 & York & PBA Twilight & 28 May & 0.1 \\
\hline K10 & 2013 & Bolgart & Kaspa & 5 June & 13 \\
\hline K11 & 2013 & Grass Patch & Kaspa & 1 June & 13 \\
\hline $\mathrm{T} 4$ & 2013 & Bolgart & PBA Twilight & 5 June & 2 \\
\hline $\mathrm{T} 5$ & 2013 & Grass Patch & PBA Twilight & 1 June & 2 \\
\hline K12 & 2014 & Bolgart & Kaspa & 11 June & 2 \\
\hline K13 & 2014 & Grass Patch & Kaspa & 22 June & 2 \\
\hline $\mathrm{T} 6^{\mathrm{c}}$ & 2014 & Bolgart & PBA Twilight & 11 June & 4 \\
\hline K14 & 2015 & Muresk & Kaspa & 29 May & 1 \\
\hline K15 & 2015 & Grass Patch & Kaspa & 22 May & 2 \\
\hline $\mathrm{T} 7$ & 2015 & Muresk & PBA Twilight & 29 May & 1 \\
\hline T8 & 2015 & Grass Patch & PBA Twilight & 22 May & 2 \\
\hline
\end{tabular}

a Each data collection block consisted of a 60-by-60-m square sown with field pea seed. The block identification number is referred to throughout the text, tables, and figures.

${ }^{\mathrm{b}}$ PSbMV infection level in seed sown established by growing 1,000 seeds from each seed stock in trays and testing seedling shoot-tip samples in groups of 2 to 10 by ELISA.

${ }^{\mathrm{c}}$ Residual wheat stubble from previous year present (approximately $75 \%$ groundcover) on soil surface. 
rapidly peaking at 77 DAS (104 aphids), then rapidly declining. Smaller numbers of three other species were caught: R. padi, Lipaphis erysimi, and Acyrthosiphon kondoi. Catches of these species commenced and peaked at 77 DAS, with 13, 8, and 4 aphids caught, respectively, before rapidly declining. In K12, which lacked residual stubble on the soil surface, aphid numbers caught by sticky traps were similar to the numbers caught in green tile traps. However, in T6, which was sown into residual stubble, aphid numbers caught in green tile traps were much

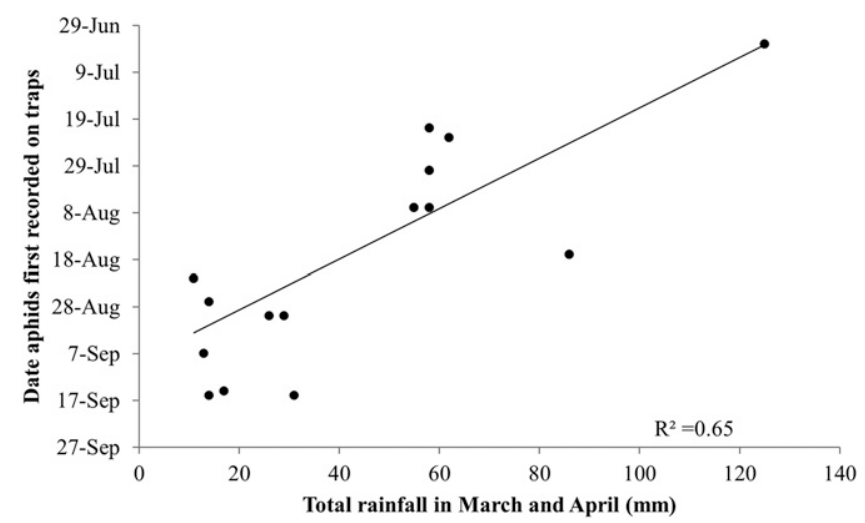

Fig. 3. Effect of total March and April rainfall on the date when winged aphids were first caught on yellow sticky traps (i.e., date of first aphid arrival). At sites in which two cultivar blocks were sown, the mean first aphid arrival date was used. smaller than those caught by sticky traps (Supplementary Fig. S2). In 2015 at the Muresk site (K14 and T7), which was surrounded by fields containing canola crops and mixed-species (legume and grass) annual pasture, numbers of aphids caught were much lower. Overall, winged migrant aphid numbers caught in green tile traps commenced at 31 DAS, rose slowly until 94 DAS before rising to a sharp peak at 105 DAS, then declined. After commencing at 45 DAS, $M$. persicae numbers caught rose slowly until 94 DAS, rapidly peaked at 107 DAS (16 aphids), then rapidly declined (Fig. 4B). L. erysimi catches commenced earlier, at 31 DAS, but then fluctuated at low levels until 100 DAS before again rapidly peaking at 107 DAS, when they reached the same numbers as $M$. persicae before rapidly declining. A. kondoi numbers caught commenced much later, at 87 DAS, but rapidly rose before peaking at 107 DAS (13 aphids) then rapidly declining. $R$. padi were absent. In both K14 and T7, aphid numbers caught in green tile traps were similar to those caught on yellow sticky traps.

Aphid colonization. No nymphs were ever found on field pea plants in any of the blocks.

Block climatic, aphid, and PSbMV incidence data. Multiple regression analysis demonstrated that both PSbMV infection level in seed sown and day of first aphid arrival significantly influenced PSbMV incidence at flowering $(P<0.001$ and $P=0.005$ respectively, $R^{2}=0.83$ ).

In 16 of the 23 blocks, PSbMV incidence at earliest sampling was lower than the infection input level in sown seed (Table 2). Greater mortality in infected than healthy seedlings is a likely cause. Alternatively, faster growth of healthy than infected seedlings or delayed germination of infected seedlings might have biased leaf sampling in
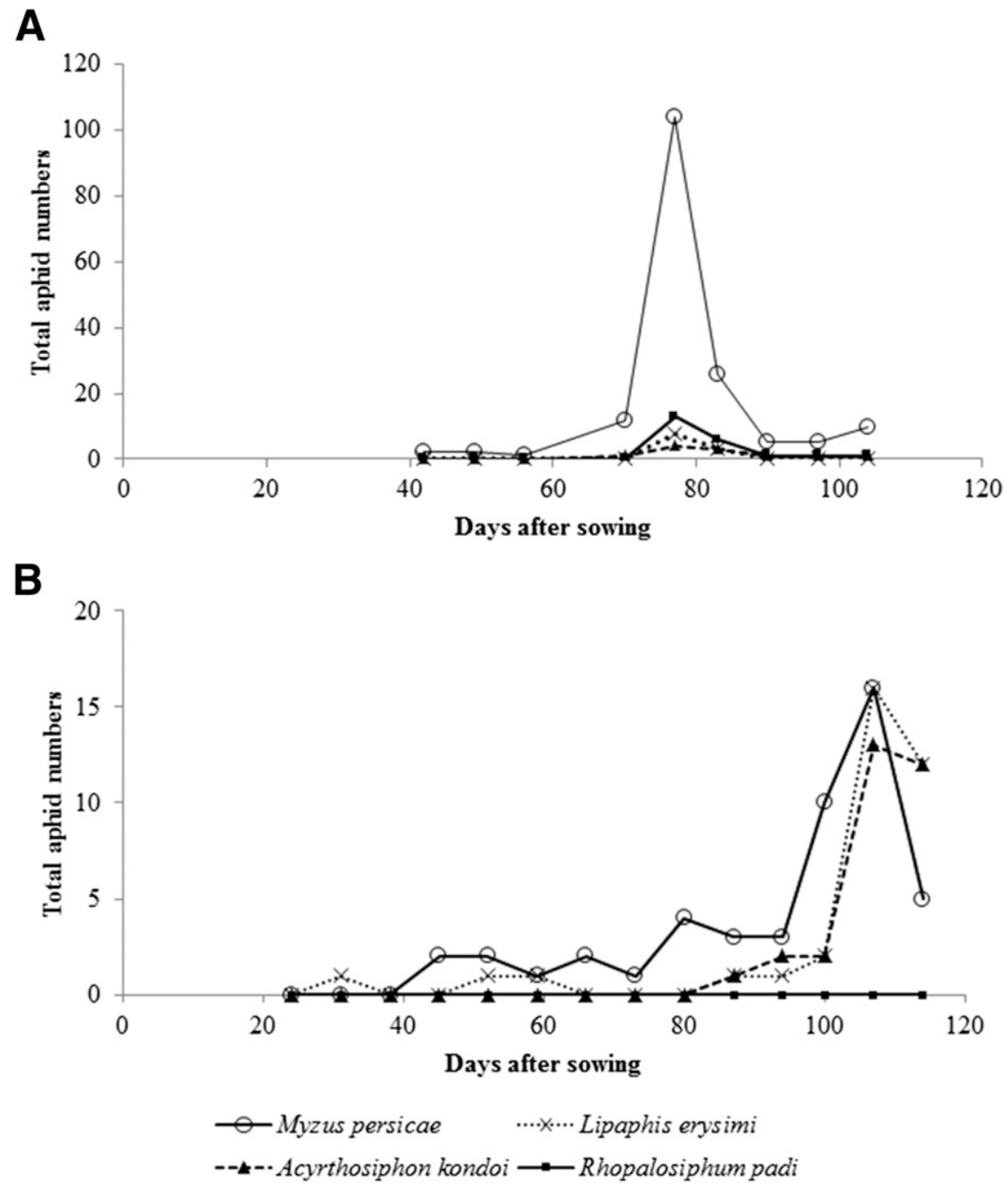

Fig. 4. Noncumulative numbers of migrant winged aphid species caught in green tile traps at different times after sowing at A, Bolgart in 2014 (K12 and T6 combined) and B, Muresk in 2015 (K14 and T7 combined). There was one green tile trap in the center of each cultivar block. 
favor of healthy seedlings because these grew quicker; thus, the seedinfected ones might have been missed beneath them. A combination of both of these seems the most likely explanation for the unexpected $0 \%$ initial incidences in $\mathrm{K} 1$ and $\mathrm{K} 2$ which were sown with 7\% infected seed following exceptionally dry March and April conditions.

High presowing rainfall scenarios $(>60 \mathrm{~mm})$. High levels of March and April rainfall preceded sowing of blocks K7, K11, $\mathrm{K} 15$, T1, T5, and T8 (Table 2). These ranged from 62 to $86 \mathrm{~mm}$ in $\mathrm{K} 7, \mathrm{~K} 15, \mathrm{~T} 1$, and $\mathrm{T} 8$ but reached $125 \mathrm{~mm}$ in $\mathrm{K} 11$ and T5. First aphid arrival based on sticky trap catches occurred on 3 July in K11 and T5, 23 July in K7 and T1, and 17 August in K15 and T8. By 100 DAS (i.e., approximately when flowering time began), PSbMV spread was very rapid and soon reached $100 \%$ in K11 (Fig. 5A). This spread was associated with sowing seed with $13 \%$ infection and a rapid increase to a high level in aphid numbers. Virus spread was also rapid and reached moderately high levels $(53 \%)$ in $\mathrm{K} 7$ (Fig. 5A). This spread was associated with sowing seed with $10 \%$ infection and occurred despite aphid numbers remaining low. In contrast, virus spread was slower but eventually reached $44 \%$ by 100 DAS in T5 (Fig. 5A). This spread was associated with sowing seed with $2 \%$ infection, representing a lower virus inoculum source, despite presence of high aphid numbers. In K15 (Fig. 5A), virus spread from an initial $2 \%$ seed infection source only reached $16 \%$ by 100 DAS. However, a rapid increase occurred between then and the final sampling, which reached $89 \%$ and was associated with a sudden late increase in aphid numbers. In the relatively early-sown T8 (22 May), also sown with $2 \%$ infected seed, only low levels of virus spread occurred by 100 DAS and this was associated with exceptionally low aphid numbers (Fig. 5A). Subsequently, following a late increase in aphid numbers after flowering, virus spread increased rapidly to $37 \%$ at final sampling. Virus spread only reached 3\% in T1 (Fig. $5 \mathrm{~A})$. This low level of spread was associated with sowing seed with very little infection $(0.1 \%)$ and presence of very low aphid numbers throughout the growing season.

Moderate presowing rainfall scenarios (40 to $60 \mathrm{~mm}$ ). Moderate levels of March and April rainfall preceded sowing of blocks K8, $\mathrm{K} 10, \mathrm{~K} 12, \mathrm{~K} 14, \mathrm{~T} 2, \mathrm{~T} 4, \mathrm{~T} 6$, and T7 (Table 2). This resulted in aphid arrival occurring between 21 July and 7 August in these blocks. By 100 DAS, PSbMV spread reached moderate levels (20 to 50\%) in T4, K14, and T7 (Fig. 5B). Aphid numbers remained low in all three blocks, which were sown with seed with 1 to $2 \%$ infection. A moderate level of virus spread that reached $57 \%$ by 100 DAS occurred in T6 (Fig. 5B), associated with sowing $4 \%$ infected seed and a marked but brief peak in aphid numbers at 85 DAS. A much higher level of spread that reached $93 \%$ by 100 DAS occurred in K10 (Fig. 5B) despite aphid numbers remaining moderately low. This spread was associated with sowing seed with a high infection level of $13 \%$. Virus spread also reached a similar level of $90 \%$ by 100 DAS in K8 (Fig. 5B), and was associated with both high early aphid numbers that peaked at 71 DAS and sowing seed with $10 \%$ infection. By 100 DAS, a high level of virus spread of $94 \%$ occurred in K12 (Fig. 5B) despite this block only being sown with seed with $2 \%$ infection. This spread was associated with exceptionally late sowing (11 June) and an early, brief peak in aphid numbers at 77 DAS. In contrast, despite aphid numbers being high, only low levels (15\%) of PSbMV spread by 100 DAS occurred in T2 (Fig. 5B). This low level of spread was associated with sowing seed with exceptionally low $(0.1 \%)$ seed infection.

Low presowing rainfall scenarios $(<40 \mathrm{~mm})$. Low levels of March and April rainfall preceded sowing of blocks K1 to K6, K9, K13, and T3 (Table 2). This resulted in aphid arrival being delayed until after August 20 in these blocks. By 100 DAS, only low levels $(<10 \%)$ of PSbMV spread had occurred in K4, K5, K6, and T3 (Fig. 5C), which were sown with seed with 2 or $0.1 \%$ infection. Virus incidence remained very low after 100 DAS $(<10 \%)$ in K4 and K5. However,

Table 2. March and April rainfall, Pea seed-borne mosaic virus (PSbMV) incidence, and aphid data obtained from field pea data collection blocks

\begin{tabular}{|c|c|c|c|c|c|c|c|c|}
\hline \multirow[b]{2}{*}{ Block $^{b}$} & \multirow[b]{2}{*}{ Rain (mm) } & \multirow[b]{2}{*}{ Seed inf $(\%)^{c}$} & \multirow[b]{2}{*}{ Arrival (DAS) $)^{d}$} & \multirow[b]{2}{*}{ Peak (DAS) $)^{\mathrm{e}}$} & \multicolumn{3}{|c|}{ PSbMV incidence $(\%)^{\mathbf{a}}$} & \multirow[b]{2}{*}{ Seed rate $(\%)^{f}$} \\
\hline & & & & & Earliest & Flowering & $\overline{\text { Final }}$ & \\
\hline $\mathrm{T} 5$ & 125 & 2 & 3 July (33) & $22(102)$ & 0 & 32 & 44 & 14 \\
\hline K11 & 125 & 13 & 3 July (33) & $27(102)$ & 2 & 98 & 100 & 21 \\
\hline $\mathrm{T} 8$ & 86 & 2 & 17 August (87) & $16(116)$ & 5 & 5 & 37 & 2 \\
\hline K15 & 86 & 2 & 17 August (87) & $17(125)$ & 2 & 20 & 89 & 4 \\
\hline $\mathrm{T} 1$ & 62 & 0.1 & 23 July (44) & $3(107)$ & 0 & 0 & 3 & 1 \\
\hline K7 & 62 & 10 & 23 July (44) & $2(101)$ & 11 & 53 & 73 & 10 \\
\hline $\mathrm{T} 7$ & 58 & 1 & 21 July (54) & $6(81)$ & 0 & 9 & 35 & 1 \\
\hline K14 & 58 & 1 & 21 July (54) & $8(81)$ & 1 & 16 & 57 & 1 \\
\hline $\mathrm{T}^{\mathrm{g}}$ & 58 & 4 & 30 July (50) & $28(77)$ & 2 & 13 & 57 & 7 \\
\hline K12 & 58 & 2 & 30 July (50) & $19(77)$ & 1 & 29 & 94 & 10 \\
\hline $\mathrm{T} 2$ & 58 & 0.1 & 7 August (58) & $26(71)$ & 1 & 11 & 24 & 8 \\
\hline K8 & 58 & 10 & 7 August (58) & $25(71)$ & 11 & 90 & 90 & 27 \\
\hline $\mathrm{T} 4$ & 55 & 2 & 7 August (63) & $5(77)$ & 1 & 24 & 37 & 8 \\
\hline K10 & 55 & 13 & 7 August (63) & $7(70)$ & 4 & 90 & 96 & 19 \\
\hline K1 & 31 & 7 & 16 September (108) & $12(129)$ & 0 & 9 & 24 & 3 \\
\hline K4 & 29 & 2 & 30 August (92) & $1(128)$ & 1 & 4 & 5 & 2 \\
\hline K5 & 26 & 2 & 30 August (96) & $3(120)$ & 4 & 8 & 9 & 4 \\
\hline $\mathrm{K} 3$ & 17 & 7 & 15 September (108) & $10(120)$ & 5 & 38 & 72 & 9 \\
\hline K13 & 14 & 2 & 27 August (66) & $20(110)$ & 1 & 24 & 82 & 3 \\
\hline $\mathrm{K} 2$ & 14 & 7 & 16 September (106) & $26(127)$ & 0 & 11 & 90 & 6 \\
\hline K6 & 13 & 2 & 7 September $(100)$ & $7(128)$ & 4 & 4 & 47 & 1 \\
\hline $\mathrm{T} 3$ & 11 & 0.1 & 22 August (86) & $15(128)$ & 1 & 8 & 24 & 1 \\
\hline K9 & 11 & 10 & 22 August (86) & $25(156)$ & 7 & 80 & 77 & 11 \\
\hline
\end{tabular}

${ }^{\text {a }}$ For leaf shoot-tip samples collected at first (earliest) sampling, flowering, and final sampling (i.e., beginning of crop senescence), 100 samples were collected systematically and tested individually or in groups of 2 to 5 by enzyme-linked immunosorbent assay (ELISA).

${ }^{\mathrm{b}}$ Each data collection block consisted of a 60-by-60-m square sown with a single field pea seed stock. The block identification number is referred to throughout the text, tables, and figures.

c Initial PSbMV seed infection.

${ }^{\mathrm{d}}$ Date of aphid arrival; days after sowing (DAS) that migrant aphids were first recorded on yellow sticky traps in parentheses.

e Peak number (highest number of aphids caught) at DAS.

${ }^{\mathrm{f}}$ Seed transmission rate. For seed harvested from central 20-by-20-m square, a sample of 1,000 seeds were grown in trays and shoot-tip samples from seedlings were tested in groups of 2 to 10 by ELISA.

${ }^{\mathrm{g}}$ Residual wheat stubble from previous year was present (approximately $75 \%$ groundcover) on soil surface. 
in K6 and T3, a late increase in PSbMV spread that reached 47 and $24 \%$, respectively, by final sampling was associated with a late increase in aphid numbers. The same pattern of spread as that in $\mathrm{K} 6$ and $\mathrm{T} 3$ also occurred in blocks $\mathrm{K} 1$ and $\mathrm{K} 2$ (Fig. 5C), which differed in being sown with $7 \%$ seed infection. The late virus spread after 100 DAS reached $24 \%$ in K1 but $90 \%$ in K2. The level of spread from this greater virus source was associated with a moderately high late increase in aphid numbers in $\mathrm{K} 1$ but a very high late increase in $\mathrm{K} 2$. In contrast, despite low early numbers of aphids and sowing seed with $7 \%$ (K3) and 10\% (K9) infection, only moderate levels of early virus spread (21 and 38\%) occurred by 100 DAS in K3 and K9 (Fig. 5C). Subsequently however, high levels of virus spread, reaching $72 \%$ (K2) and 80\% (K9), occurred after 100 DAS associated with late increases in aphid numbers. Despite being sown with seed with $2 \%$ PSbMV infection, a high level of 70\% virus spread occurred by 100 DAS in K13 (Fig. 5C). This spread was associated with extremely late sowing (22 June) and a sharp increase in aphid numbers just before 100 DAS. Moreover, the PSbMV spread in K2, K3, K9, and K13 occurred ahead of increases in aphid numbers recorded on their sticky traps.

Seed transmission. When the relationship between percent PSbMV incidence at flowering, cultivar, and percent PSbMV transmission rate from harvested seed in all blocks was examined by multiple regression, incidence at flowering significantly influenced seed transmission rate $(P<0.001$; Fig. 6$)$. However, there was no significant effect of cultivar on seed transmission rate $(P=0.23)$.

Deductions from epidemic scenarios and conceptual model. The predominant importance of March and April rainfall in driving first aphid arrival date and PSbMV spread in the early growth stage of the crop before flowering (i.e., prior to 100 DAS) was illustrated by comparing data collected from blocks K6 and T5. Both were sown with $2 \%$ PSbMV-infected seed. T5 provided a high-risk situation because it received very high levels of presowing rainfall $(125 \mathrm{~mm})$; thus, there was substantial growth of background vegetation by sowing time, which supported rapid aphid population growth. Consequently, first migrant aphid arrival was early (on 3 July), resulting in considerable PSbMV spread (32\%) by flowering time. By contrast, K6 was a lowrisk situation, in which conditions during March and April were very dry (only $13 \mathrm{~mm}$ rainfall), which meant that there was minimal growth of background vegetation by sowing time that was sufficient to support only minimal aphid populations. Therefore, aphid arrival was delayed by 2 months (until 7 September), as was their subsequent build up. Consequently, PSbMV spread was still very low (only 4\%) by flowering time at approximately 100 DAS. Also in contrast to the T5 scenario, low March and April rainfall in K1 (31 mm), K4 (29 mm), K6 $(13 \mathrm{~mm})$, and T3 $(11 \mathrm{~mm})$ resulted in late aphid arrival (30 August to 16 September) and negligible levels of PSbMV spread by flowering (4 to $9 \%$ ). Where late spread occurred after flowering following late aphid arrival (e.g., T3, T8, and K15), this was associated with substantial late migrant numbers caught on yellow sticky traps in these blocks.

The predominant importance of PSbMV infection levels in seed sown was illustrated by the scenarios that unfolded in blocks $\mathrm{K} 3$ and K6 sown with Kaspa seed with 7\% (K3) and 2\% (K6) infection. Despite both blocks being sown in low-risk situations following 13 to $17 \mathrm{~mm}$ of March and April rainfall, resulting in late first aphid arrival
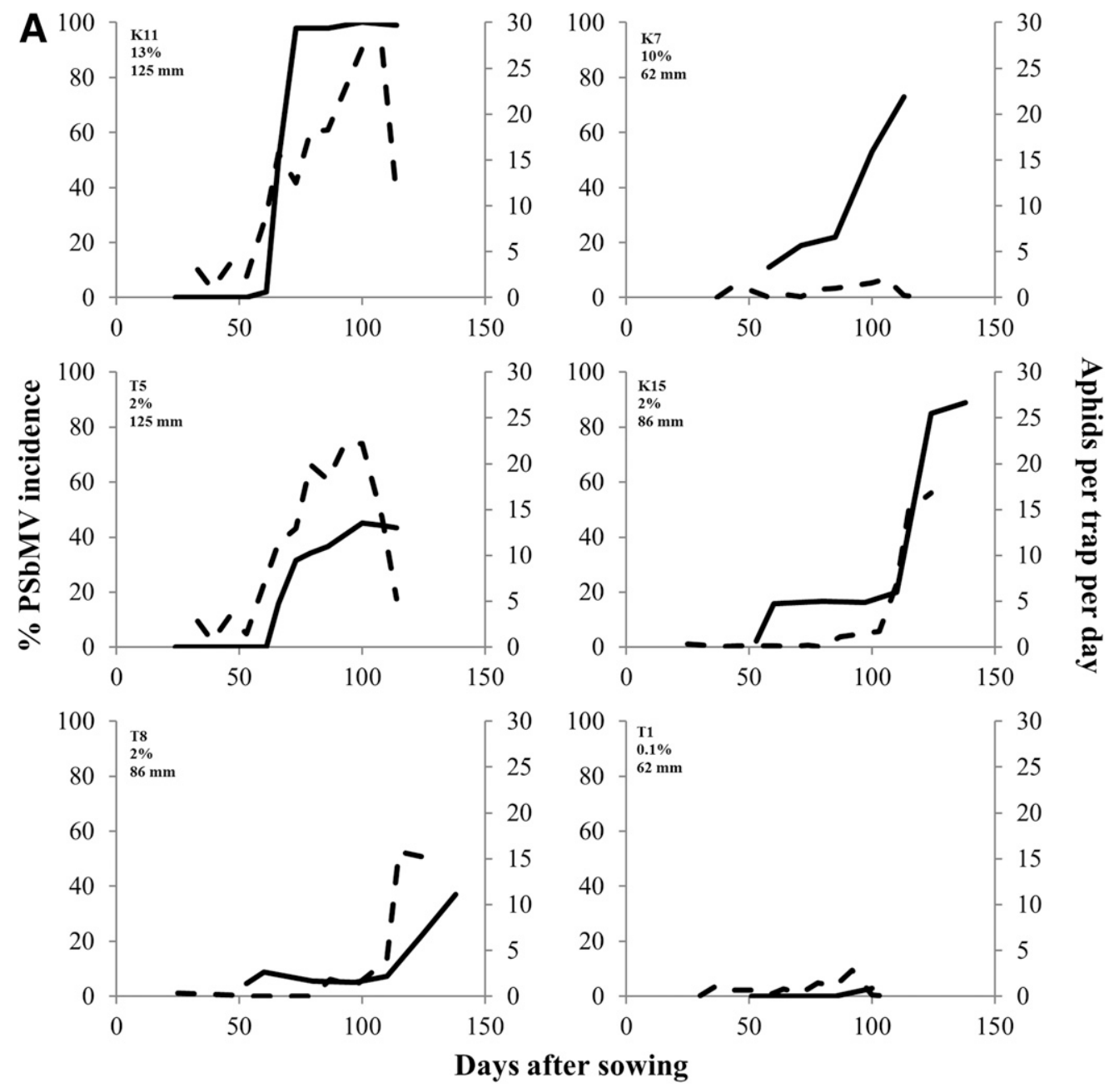

Continued on next page Fig. 5. Pea seed-borne mosaic virus (PSbMV) incidence (\%, solid line) and aphid numbers caught on sticky traps (dashed line) during the growing season in field pea data collection blocks sown following A, high (>60 mm); B, moderate (40 to $60 \mathrm{~mm})$; and C, low $(<40 \mathrm{~mm})$ March and April rainfall. Block identification number and percent PSbMV infection in seed sown and total March and April rainfall indicated at top left of each graph. 
(7 to 15 September), by flowering time, K3 had far higher PSbMV spread (38\%) than K6 (4\%). Thus, even when rainfall during March and April was minimal and aphid arrival was late, substantial PSbMV spread still occurred when seed with a higher level of infection was sown. The effect of sowing seed with minimal infection in a highrisk situation was illustrated by the scenarios that occurred in blocks $\mathrm{T} 1$ and T2, both sown following 58 to $62 \mathrm{~mm}$ of March and April rainfall. In both, the PBA Twilight seed sown had only 0.1\% PSbMV infection; therefore, despite early aphid arrival (23 July to 7 August) and subsequent aphid abundance, by flowering time PSbMV spread was still minimal, with no spread detected in $\mathrm{T} 1$ and only $11 \%$ incidence in $\mathrm{T} 2$. In contrast, $\mathrm{K} 8, \mathrm{~K} 10$, and $\mathrm{K} 11$ represented worst-case scenarios because they were sown with 10 to $13 \%$ PSbMV-infected seed in high- risk situations following 55 to $125 \mathrm{~mm}$ of March and April rainfall. In consequence, PSbMV incidence reached 90 to $98 \%$ by flowering time in these blocks.

The suspected occurrence of wind-mediated contact transmission was illustrated by the scenarios in $\mathrm{K} 15$ and T8, which were high-risk situations with high levels of rainfall in March and April $(86 \mathrm{~mm})$. However, first aphid arrival was delayed until midAugust. Despite absence of aphid catches during the early part of the growing season, some PSbMV spread still occurred (20\% in $\mathrm{K} 15$ and $5 \%$ in T8). High increases in virus spread also occurred in the presence of exceptionally low aphid numbers in K7 (high preseason rainfall scenario) and in K2, K3, K9, and K13 (low preseason rainfall scenarios). In the latter cases, this spread preceded the

Continued from preceeding page
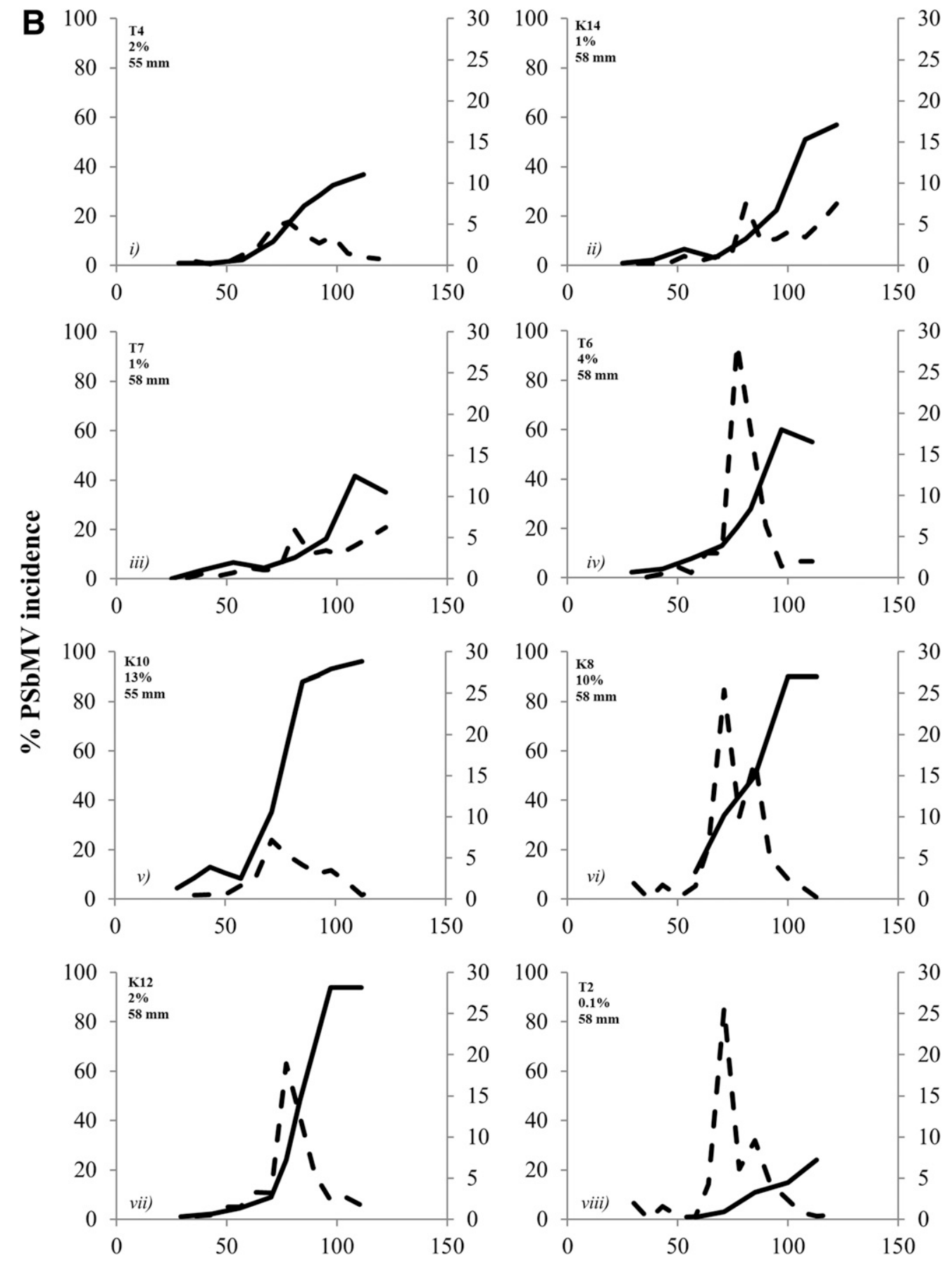

Days after sowing 
corresponding late increase in aphid numbers. Although windspeed data were unavailable for these sites to help support this deduction, such scenarios are consistent with the possibility of wind-mediated contact transmission.

The likely influence of sowing date on PSbMV spread was illustrated by comparing scenarios involving sowing in late May in K5 (sown 26 May) as opposed to mid- to late June in K13 (22 June). Despite both being sown with seed with $2 \%$ PSbMV infection in low-risk situations following 14 to $26 \mathrm{~mm}$ of March and April rainfall, K13 developed a much higher incidence by flowering time (24\%) than K5 (8\%). This is consistent with delayed flowering in K13, which was sown $>3$ weeks later. The suspected effect of groundcover in reducing aphid landing rates was illustrated by the reduced aphid numbers caught landing in green tile traps in the presence of stubble on the soil surface in T6 compared with the neighboring K12, which lacked stubble.

Continued from preceeding page
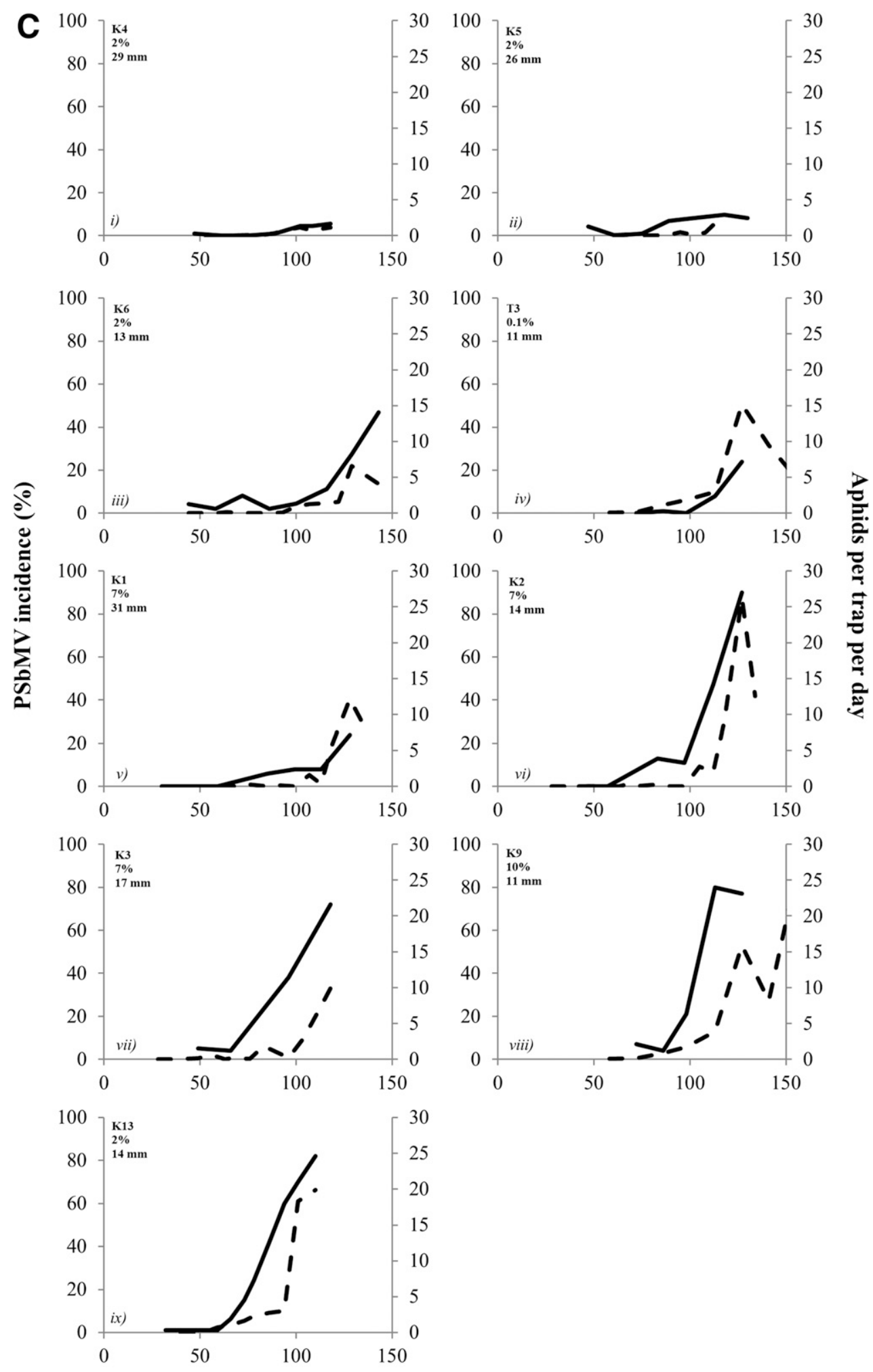

Days after sowing 
The possibility of partial PSbMV resistance in reducing PSbMV spread was illustrated by PSbMV incidences in Kaspa and PBA Twilight in blocks K14 and T7. Spread was greater in K14 (16 to 57\% between flowering and final sampling) than T7 (9 to 35\%), despite both these blocks being sown with $1 \%$ PSbMV seed infection and located next to each other.

These deductions on primary (seed infection and March and April rainfall) and likely secondary (wind, sowing date, groundcover, and partial resistance) epidemic drivers were used to develop general conceptual models of PSbMV-field pea epidemiology in high- and low-risk situations (Fig. 7).

\section{Discussion}

This study revealed that, despite lack of crop colonization by aphids, the PSbMV-field pea pathosystem exhibits epidemiological characteristics similar to those of other aphidborne virus pathosystems of broadscale, annual, rainfed crops examined previously in the southwest Australian grainbelt. The predominant influences on the rate and magnitude of PSbMV spread in field pea crops deduced were (i) magnitude of virus infection in seed sown and (ii) rainfall in early to mid-autumn (March and April). These were illustrated by data obtained from 23 field pea data collection blocks sown over 6 years at five locations representing diverse climatic scenarios. The first major epidemic driver was PSbMV infection in seed sown because it dictated the number of initial PSbMV infection foci for (i) migrant aphids to acquire and spread the virus and (ii) likely spread to neighboring plants by windmediated contact transmission. The second major epidemic driver was date of first aphid arrival which, in turn, depended upon the amount of March and April rainfall. High amounts of rainfall $(>60 \mathrm{~mm}$ ) during this period resulted in early first aphid arrival to the blocks leading to early virus spread from within-crop infection foci originating from seed-infected plants and, depending on the magnitude of these infection foci, potentially high PSbMV incidences by flowering time. In contrast, low amounts of March and April rainfall $(<40 \mathrm{~mm})$ resulted in late first aphid arrival, which limited PSbMV spread by aphids to later in the growing season. Likely secondary epidemic drivers indicated by some of the collection block data were wind (by mediating contact transmission) and sowing date (by altering the growth stage exposed to migrant aphids). Possible other secondary drivers were presence of groundcover (by reducing aphid landing rates) and partial resistance. Moreover, PSbMV transmission rate from harvested seed was significantly influenced by its incidence at flowering time.

The critical influence of seedborne infection on the epidemiology of PSbMV in field pea illustrated in this study is consistent with the findings of Coutts et al. (2009), in which field pea seed lots with a range of different PSbMV seed infection levels were sown in plots in replicated field experiments. In their study, crop PSbMV incidence toward the end of the growing period depended upon the virus infection level in the seed sown and determined the magnitude of subsequent yield loss and transmission rate from harvested seed. For example, in high-risk situations involving early aphid arrival, seed infection levels of $6.5 \%$ led to $97 \%$ final incidence, which resulted in seed yield losses of $25 \%$, whereas sowing seed with $0.3 \%$ infection led to $9 \%$ final incidence, which resulted in negligible seed yield losses. A similar relationship between amount of initial seed infection, magnitude of virus spread, yield loss, and seed transmission rate from harvested seed occurred with the Cucumber mosaic virus (CMV; family Bromoviridae, genus Cucumovirus)-narrow-leafed lupin pathosystem (Bwye et al. 1994). In our study on PSbMV in the same region, which used multiple data collection blocks rather than the large-scale replicated field experiment approach used in these two earlier studies, seed was sown with 0.1 to $13 \%$ infection. Sowing seed with higher levels of PSbMV infection $(>6.5 \%)$ in a high-risk situation often resulted in $>90 \%$ incidence by flowering time. Therefore, yield losses would be expected to be $>25 \%$, which would, in practice, eliminate grower profit margin. High incidence at flowering has a greater impact on the magnitude of yield loss than when such incidences are only reached by the end of the growing season. This is because substantial early spread results in greater reduction in plant growth, leading to greater seed yield and quality losses (Ali and Randles 1998; Coutts et al. 2009; Kraft and Hampton 1980). The significant relationship between PSbMV incidence around the time of flowering and PSbMV transmission rate from harvested seed shown in our study also agrees with the findings of Coutts et al. (2009).

As with other aphidborne virus pathosystems studied previously in the southwest Australian grainbelt, such as CMV and Bean yellow mosaic virus (BYMV; family Potyviridae, genus Potyvirus) in narrowleafed lupin, Barley yellow dwarf virus (family Luteoviridae, genus Luteovirus) in wheat, and Beet western yellows virus (synonym: Turnip yellows virus; family Luteoviridae, genus Polerovirus) in canola (Jones 2001; Maling et al. 2008, 2010; Thackray et al. 2004, 2009), March and April rainfall prior to sowing strongly influenced time of first aphid arrival to the field pea data collection blocks. These migrant aphids were a primary epidemic driver because they spread the virus originating from internal infection sources to nearby healthy plants within the blocks. As mentioned above, background aphid populations that develop in the presowing period produce winged migrants consisting of crop-colonizing and noncolonizing species, both of which are important for virus spread. The aphid data obtained in these earlier studies with other pathosystems came from a combination of largescale field experiments and data collection blocks (referred to as validation or calibration blocks). Our studies with PSbMV differed in that (i) data collection blocks alone were used to obtain aphid data and (ii) PSbMV spread was only by noncolonizing migrant winged aphids, with no contribution from aphids that might have colonized the field pea crop. Despite these differences, the predominant influence of March and April rainfall on the magnitude of virus spread was the same. However, in a few instances, late aphid arrival and low aphid numbers occurred in blocks sown following high March and April rainfall. This could be due to (i) aphid mortality from heavy rain during storm events that occurred before sowing time, (ii) insecticide applications to nearby crops that restricted background aphid populations, (iii) abundance of entomopathogenic fungi or natural aphid predators, or (iv) a combination of these factors.

Surrounding crops influenced which winged migrant aphid species were caught in green tile traps. For example, blocks K14 and T7 were surrounded by fields containing canola crops and mixed-species (legume and grass) annual pasture. L. erysimi, which colonizes canola in the grainbelt (Jones et al. 2007); A. kondoi, which colonizes annual pasture legume plants (Jones 2004); and M. persicae, which colonizes both (Jones 2004; Jones et al. 2007) were present in the traps. In K12 and T6, R. padi were also found in the traps and were probably coming from a nearby wheat crop (Thackray et al. 2009). R. padi and M. persicae both transmit PSbMV (Gonzalez and Hagedorn 1971; Karl and Schmidt 1978). In an earlier study, U.S. clones of M. persicae were efficient PSbMV vectors. However, in the same study, transmission efficiency varied between biotypes of the same species (Gonzalez and Hagedorn 1971). Therefore, to establish their relative roles as PSbMV

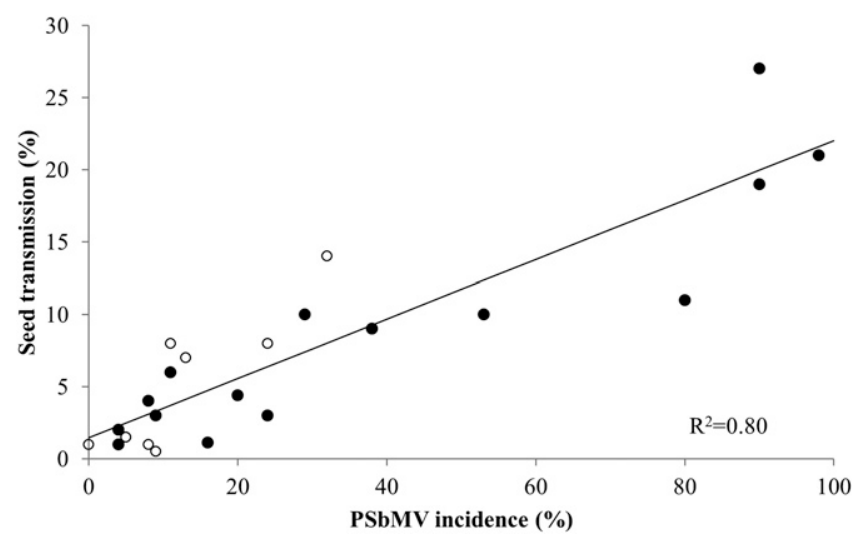

Fig. 6. Relationship between the percent Pea seed-borne mosaic virus (PSbMV) seed transmission rate from harvested seed and incidence at flowering in blocks of Kaspa (-) and PBA Twilight (O). No significant effect of cultivar was found; thus, data from both Kaspa and Twilight were included in the figure. 
vectors, transmission efficiency studies need to be done using biotypes of M. persicae, R. padi, and other prominent species found in the grainbelt. Furthermore, it is unknown whether A. kondoi and L. erysimi transmit PSbMV; thus, their transmission abilities need to be evaluated. They are both vectors of two other common nonpersistently transmitted aphidborne viruses, CMV and BYMV, in narrow-leafed lupin crops in the grainbelt (Berlandier et al. 1997).
Rice yellow mottle virus (RYMV; family Sobemoviridae, genus Sobemovirus) is transmitted by wind-mediated contact between infected and healthy rice (Oryza sativa) plants. This was demonstrated in field experiments in which transmission occurred in wind-exposed rice plots but not in wind-protected plots. Contact transmission occurred via small leaf wounds caused by wind-assisted friction between RYMV-infected and healthy rice plants (Sarra et al. 2004).

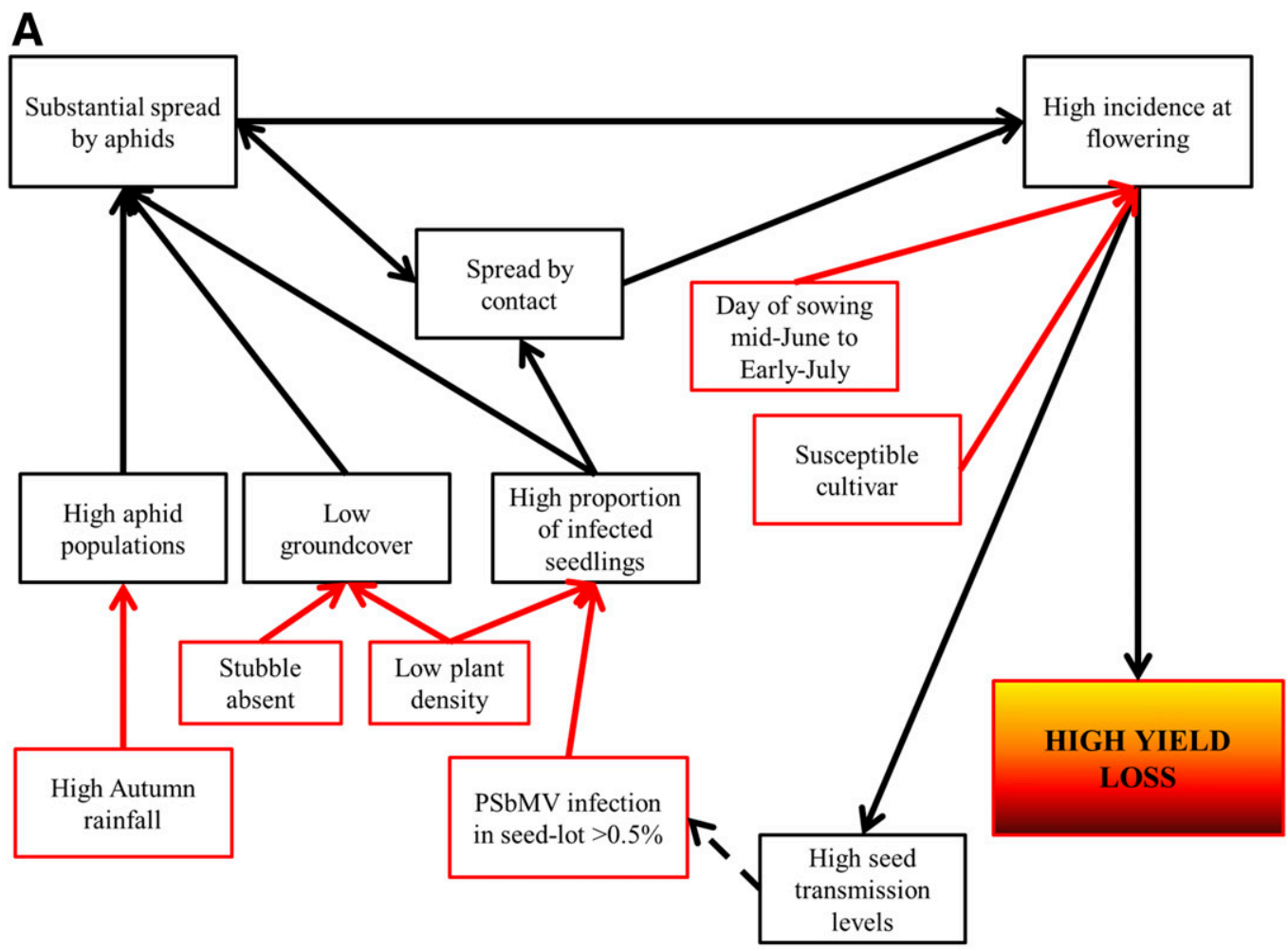

B

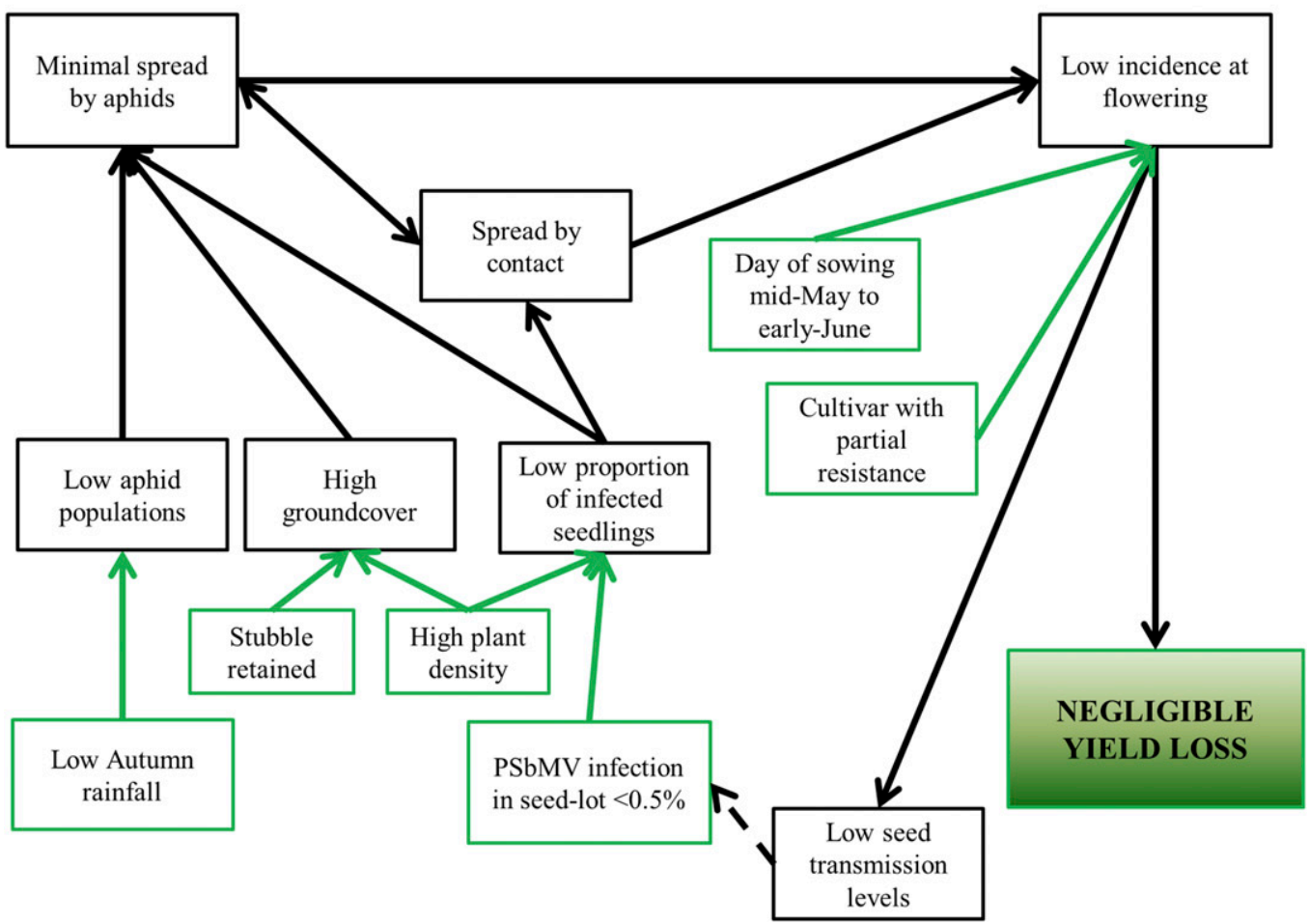

Fig. 7. Conceptual model for epidemiology of the Pea seed-borne mosaic virus (PSbMV)-field pea pathosystem in a Mediterranean-type environment in A, high-risk and B, low-risk situations. Red lines signify drivers of high PSbMV incidence and green lines signify drivers of low PSbMV incidence. 
Wind-mediated PSbMV contact transmission between infected and heathy field pea plants was demonstrated under glasshouse conditions (Congdon et al. 2016b). Anecdotal evidence, in which high levels of PSbMV spread occurred before migrant aphids arrived in large-scale, replicated field experiments (Coutts et al. 2009), suggested that wind-mediated PSbMV contact transmission also occurs under natural conditions. In our study, PSbMV spread by windmediated contact transmission was a likely explanation in scenarios in which PSbMV spread occurred despite aphids being absent or in exceptionally low numbers, or where rapid increases in PSbMV incidence occurred well before corresponding increases in migrant aphid numbers. Although not yet demonstrated in replicated field experiments like those of Sarra et al. (2004), as mentioned above, such spread would accelerate epidemics by enlarging initial PSbMV infection foci before subsequent spread by migrant aphids arriving later in the growing season (Congdon et al. 2016b). Scenarios that involve an increase in virus incidence prior to a corresponding aphid number increase are unusual. In similar pathosystems where aphids colonize the crop, a sharp increase in colonizing aphid numbers precedes a corresponding increase in virus incidence (Jones et al. 2003; Thackray et al. 2000). In addition to wind-mediated contact transmission, another possible factor in these PSbMV epidemic scenarios was that sticky traps in most of these blocks were not fixed, so they were susceptible to movement by wind currents and may not have faced the predominant wind direction. This might tend to delay the recorded date of first aphid arrival and diminish the total numbers caught. However, this alone would be insufficient to explain such large lags between incidence and recorded aphid numbers as those found in blocks $\mathrm{K} 3, \mathrm{~K} 9$, and $\mathrm{K} 13$.

Sowing at a later stage of the growing season (mid- to late June) creates more opportunity for PSbMV to spread while the crop is at its vulnerable early growth stage prior to flowering which, as mentioned above, results in greater seed yield losses. This is because later sowing reduces the period between sowing date and aphid arrival, such that plants are younger when this occurs. Although not explored in this study, sowing even earlier than the earliest times used in our study and, thereby, exposing young plants to high autumn aphid populations when conditions are warm can result in first aphid arrival and consequent widespread CMV spread very early in the life of narrowleafed lupin crops (Jones 2001); this might have a similar effect in the PSbMV-field pea pathosystem. The impact of groundcover, in the form of residual stubble on the soil surface, in reducing aphid landings prior to canopy closure observed at Bolgart in 2014 is consistent with findings with stubble groundcover in large-scale field experiments with the BYMV-narrow-leafed lupin pathosystem in the same region. In those studies, aphid landing rates were reduced by straw groundcover which, in turn, reduced BYMV spread (Jones 1994, 2001).

Currently, 'PBA Wharton' and 'Yarrum' are the only Australian semileafless field pea cultivars available with comprehensive sbm1 gene PSbMV resistance (van Leur et al. 2013). However, Yarrum is unsuitable for southwest Australian grainbelt growing conditions and PBA Wharton was only introduced commercially in 2014; thus, its suitability is yet to be established. Also, a small proportion of PBA Wharton and Yarrum plants became infected following mechanical inoculation with a local PSbMV isolate, suggesting that their resistance effectiveness in the field needs to be monitored and using PBA Wharton prophylactically every season should be avoided (Congdon et al. 2016a). The presence of partial resistance to PSbMV infection in PBA Twilight deduced in this study is consistent with earlier findings demonstrating its partial resistance to mechanical inoculation with PSbMV (Congdon et al. 2016a). Therefore, PBA Twilight might be worth sowing in preference to Kaspa when a high-risk situation is forecasted and healthy seed stocks are unavailable.

This study also illustrates the dangers inherent in retaining seed from field pea crops grown in high-risk situations for sowing the following growing season. The PSbMV transmission rates from harvested seed were $>5 \%$ in 11 of 23 data collection blocks; therefore, such seed is likely to be too risky to sow in the following growing season regardless of the anticipated risk level based on amount of March and April rainfall. In 3 of 11 of these cases, seed transmission rates were $>19 \%$. Even in a low-risk situation, sowing seed with such high levels of seedborne infection would likely lead to unacceptably high PSbMV-induced losses. Occurrence of such high infection levels demonstrates how rapidly PSbMV infection can build up in field pea seed stocks, resulting in substantial losses when they are sown in a high-risk year. This reinforces the importance of (i) having representative seed samples tested to establish seed infection levels in seed stocks to be used for sowing and (ii) sourcing healthy (i.e., $<0.5 \%$ infected) seed.

The data collected in this study provide ideal information to use to calibrate and validate a predictive model for PSbMV epidemics in field pea crops. This would use March and April rainfall data to forecast aphid numbers, in combination with PSbMV infection levels in seed stocks to be sown to forecast subsequent virus incidences in crops. As mentioned earlier, this was done previously with other annual crop pathosystems involving aphidborne viruses in the same region. Utilizing such a model to inform a DSS that forecasts a high PSbMV risk season prior to sowing would forewarn an end-user to obtain healthy seed (i.e., $<0.5 \%$ infection depending on the risk level), implement control strategies that minimize the spread and economic impact of $\mathrm{PSbMV}$, and potentially employ host resistance. Location-specific critical thresholds for seed PSbMV infection could also be provided to optimize PSbMV management. In contrast, a low-risk season forecast would permit the same end-user to avoid taking unnecessary precautions and, thus, avoid wasting their resources without compromising production (Congdon et al. 2014, 2016a,c). Such forecasts would assist greatly with controlling PSbMV in field pea crops, thereby minimizing the financial losses experienced by growers.

\section{Acknowledgments}

We thank B. E. Gajda, M. A. Kehoe, and M. Banovic for assisting with data collection and ELISA testing of samples from the 2010 to 2012 data collection blocks; S. J. Vincent for glasshouse support; and R. de Gruchy, C. Matthews, and J. Delroy for sowing and harvesting the data collection blocks. This research was funded by Australian Research Council Linkage Project LP120200224, the Department of Agriculture and Food Western Australia (DAFWA), and the Australian Grains Research and Development Corporation Project DAW00228. The laboratory and glasshouse component of this research was done using the facilities of DAFWA.

\section{Literature Cited}

Aapola, A. A., and Mink, G. I. 1973. Potential aphid vectors of pea seedborne mosaic virus in Washington. Plant Dis. Rep. 57:552.

Ali, A., and Randles, J. W. 1998. The effects of two pathotypes of pea seed-borne mosaic virus on the morphology and yield of pea. Australas. Plant Pathol. 27:226-233.

Berlandier, F. A., Thackray, D. J., Jones, R. A. C., Latham, L. J., and Cartwright, L. 1997. Determining the relative roles of different aphid species as vectors of cucumber mosaic and bean yellow mosaic viruses in lupins. Ann. Appl. Biol. 131:297-314.

Bwye, A. M., Jones, R. A. C., and Proudlove, W. 1994. Effects of sowing seed with different levels of infection, plant-density and the growth stage at which plants first develop symptoms on cucumber mosaic-virus infection of narrow-leafed lupins (Lupinus angustifolius). Aust. J. Agric. Res. 45:1395-1412.

Chalk, P. M. 1998. Dynamics of biologically fixed N in legume-cereal rotations: A review. Aust. J. Agric. Res. 49:303-316

Chiko, A. W., and Zimmer, R. C. 1978. Effect of pea seed-borne mosaic virus on two cultivars of field pea grown in Manitoba. Can. J. Plant Sci. 58:1073-1077.

Clark, M. F., and Adams, A. N. 1977. Characteristics of the microplate method of enzyme-linked immunosorbent assay for the detection of plant viruses. J. Gen. Virol. 34:475-483.

Congdon, B. S., Coutts, B. A., Renton, M., Banovic, M., and Jones, R. A. C. 2016a. Pea seed-borne mosaic virus in field pea: Widespread infection genetic diversity and resistance gene effectiveness. Plant Dis. 100:2475-2482.

Congdon, B. S., Coutts, B. A., Renton, M., and Jones, R. A. C. 2016b. Pea seedborne mosaic virus: Stability and wind-mediated contact transmission in field pea. Plant Dis. 100:953-958.

Congdon, B. S., Coutts, B. A., Renton, M., and Jones, R. A. C. 2016c. Pea seedborne mosaic virus epidemiology in a Mediterranean-type environment. (Abstr.) in: Proc. 13th Int. Plant Virus Epidemiol. Symp. Avignon, France.

Congdon, B. S., Renton, M., Coutts, B. A., Van Leur, J. A. G., and Jones, R. A. C. 2014. Understanding, managing and forecasting Pea seed-borne mosaic virus in field pea. (Abstr.) Page 34 in: Proc. 11th Australas. Plant Virol. Workshop, Brisbane, Australia.

Coutts, B. A. 2016. Pea seed-borne mosaic virus in field peas. Online publication. Department of Agriculture and Food, South Perth, Australia. https://www.agric. wa.gov.au/field-peas/pea-seed-borne-mosaic-virus-field-peas

Coutts, B. A., Prince, R. T., and Jones, R. A. C. 2008. Further studies on Pea seedborne mosaic virus in cool-season crop legumes: Responses to infection and seed quality defects. Aust. J. Agric. Res. 59:1130-1145. 
Coutts, B. A., Prince, R. T., and Jones, R. A. C. 2009. Quantifying effects of seedborne inoculum on virus spread, yield losses, and seed infection in the Pea seed-borne mosaic virus-field pea pathosystem. Phytopathology 99:1156-1167.

Gibbs, A. J., and Gower, J. C. 1960. The use of a multiple-transfer method in plant virus transmission studies - some statistical points arising in the analysis of results. Ann. Appl. Biol. 48:75-83.

Gladstones, J. S. 1998. Distribution, origin, taxonomy, history and importance. Pages 1-40 in: Lupins as Crop Plants-Biology, Production and Utilization. J. S. Gladstones, C. Atkins, and J. Hamblin, eds. Cambridge University Press, Cambridge.

Gonzalez, L. C., and Hagedorn, D. J. 1971. The transmission of pea seed-borne mosaic virus by three aphid species. Phytopathology 61:825-828.

Inouye, T. 1967. A seed-borne mosaic virus of pea. Ann. Phytopathol. Soc. Jpn. $33: 38-42$.

Jones, R. A. C. 1994. Effect of mulching with cereal straw and row spacing on spread of bean yellow mosaic potyvirus into narrow-leafed lupins (Lupinusangustifolius). Ann. Appl. Biol. 124:45-58.

Jones, R. A. C. 2001. Developing integrated disease management strategies against non-persistently aphid-borne viruses: A model programme. Integr. Pest Manage. Rev. 6:15-46.

Jones, R. A. C. 2004. Using epidemiological information to develop effective integrated virus disease management strategies. Virus Res. 100:5-30.

Jones, R. A. C., Coutts, B. A., and Cheng, Y. 2003. Yield limiting potential of necrotic and non-necrotic strains of Bean yellow mosaic virus in narrowleafed lupin (Lupinus angustifolius). Aust. J. Agric. Res. 54:849-859.

Jones, R. A. C., Coutts, B. A., and Hawkes, J. 2007. Yield-limiting potential of Beet western yellows virus in Brassica napus. Aust. J. Agric. Res. 58:788-801.

Jones, R. A. C., and Proudlove, W. 1991. Further studies on cucumber mosaic virus infection of narrow-leafed lupin (Lupinus angustifolius): Seed-borne infection, aphid transmission, spread and effects on grain yield. Ann. Appl. Biol. 118:319-329.

Jones, R. A. C., Salam, M. U., Maling, T. J., Diggle, A. J., and Thackray, D. J. 2010. Principles of predicting plant virus disease epidemics. Annu. Rev. Phytopathol. 48:179-203.

Karl, E., and Schmidt, H. E. 1978. Untersuchungen zum Artenspektrum der Aphidenvektoren des Erbsenblattrollmosaik-virus (pea leaf rolling mosaic virus). Arch. Phytopathol. Pflanzenschutz 14:367-372.

Khetarpal, R. K., and Maury, Y. 1987. Pea seed-borne mosaic virus: A review. Agronomie 7:215-224.

Kraft, J. M., and Hampton, R. O. 1980. Crop losses from pea seedborne mosaic virus in six processing pea cultivars. Plant Dis. 64:922-924.

Latham, L. J., and Jones, R. A. C. 2001a. Incidence of virus infection in experimental plots, commercial crops, and seed stocks of cool season crop legumes. Aust. J. Agric. Res. 52:397-413.
Latham, L. J., and Jones, R. A. C. 2001b. Alfalfa mosaic and pea seed-borne mosaic viruses in cool season crop, annual pasture, and forage legumes: Susceptibility, sensitivity, and seed transmission. Aust. J. Agric. Res. 52: 771-790

Maling, T., Diggle, A. J., Thackray, D. J., Siddique, K. H., and Jones, R. A. C. 2008. An epidemiological model for externally sourced vector-borne viruses applied to Bean yellow mosaic virus in lupin crops in a Mediterranean-type environment. Phytopathology 98:1280-1290.

Maling, T., Diggle, A. J., Thackray, D. J., Siddique, K. H. M., and Jones, R. A. C. 2010. An epidemiological model for externally acquired vector-borne viruses applied to Beet western yellows virus in Brassica napus crops in a Mediterranean-type environment. Crop Pasture Sci. 61:132-144.

Sarra, S., Oevering, P., Guindo, S., and Peters, D. 2004. Wind-mediated spread of Rice yellow mottle virus (RYMV) in irrigated rice crops. Plant Pathol. 53: 148-153.

Siddique, K. H. M., Loss, S. P., Regan, K. L., and Jettner, R. L. 1999. Adaptation and seed yield of cool season grain legumes in Mediterranean environments of south-western Australia. Aust. J. Agric. Res. 50:375-388.

Thackray, D. J., Diggle, A. J., Berlandier, F. A., and Jones, R. A. C. 2004 Forecasting aphid outbreaks and epidemics of Cucumber mosaic virus in lupin crops in a Mediterranean-type environment. Virus Res. 100:67-82.

Thackray, D. J., Diggle, A. J., and Jones, R. A. C. 2009. BYDV Predictor: A simulation model to predict aphid arrival, epidemics of Barley yellow dwarf virus and yield losses in wheat crops in a Mediterranean-type environment. Plant Pathol. 58:186-202.

Thackray, D. J., Jones, R. A. C., Bwye, A. M., and Coutts, B. A. 2000. Further studies on the effects of insecticides on aphid vector numbers and spread of cucumber mosaic virus in narrow-leafed lupins (Lupinus angustifolius). Crop Prot. 19:121-139.

Thackray, D. J., Ward, L., and Jones, R. A. C. 1998. Aphid arrival and build up in relation to BYDV levels and yield loss. Pages 60-61 in: 1998 Cereals Updates. W. Anderson and J. Blake, eds. Agriculture Western Australia, Perth, Australia.

Thackray, D. J., Ward, L. T., Thomas-Carroll, M. L., and Jones, R. A. C. 2005 Role of winter-active aphids spreading Barley yellow dwarf virus in decreasing wheat yields in a Mediterranean-type environment. Aust. J. Agric. Res. 56:1089-1099.

van Leur, J. A. G., Kumari, S. G., Aftab, M., Leonforte, A., and Moore, S. 2013. Virus resistance of Australian pea (Pisum sativum) varieties. N. Z. J. Crop Hortic. 41:86-101.

Vincent, S. J., Coutts, B. A., and Jones, R. A. C. 2014. Effects of introduced and indigenous viruses on native plants: Exploring their disease causing potential at the agro-ecological interface. PLoS One 9:e91224. 